\title{
National and Patriotic Traditions of Upbringing in Russia: History and Modernity
}

\author{
Vyacheslav Erokhin ${ }^{1, a}$, Tatiana Kostyukova ${ }^{2}$, and Natalya Galtsova ${ }^{3}$ \\ ${ }^{1}$ Tomsk Polytechnic University, 634050 Lenin Avenue, 30, Tomsk, Russia \\ ${ }^{2}$ Tomsk State University, 634050 Lenin Avenue, 36, Tomsk, Russia \\ ${ }^{3}$ Tomsk Agricultural Institute - a branch of the Novosibirsk State Agrarian University
}

\begin{abstract}
The paper discusses survey results of a complex and multifaceted phenomenon - the fundamentals of national education and upbringing of younger generations. It is known that the idea of multiculturalism in upbringing is currently recognized as untenable. That is why Europe and other countries of the world, again, turned to the basics of traditional upbringing, where religions continue to hold their place like a moral tuning fork.
\end{abstract}

\section{Introduction}

The problem of preserving or denial of traditions in various areas of unstable modern society, Russian in particular, is one of the dominant problems of social existence. It is the tradition, understood as the preservation and passing along the historical customs and moral rules of life, that today is increasingly becoming the cornerstone in educational systems of many countries.

The problem of national and patriotic education and upbringing of younger generations is still very significant all over the world as well as in Russia. The Russian Federation has already been included in the processes of globalization and world market space together with the most developed countries. The implemented state programs of patriotic education and upbringing of Russian citizens (2001-2015) confirmed this thesis. These programs took into account the multinational and multi-religious factor of the country. The fourth state program of Russian younger generations for the period of 2016-2020 is being implemented now in order to form civic and patriotic consciousness and good conditions for spiritual and cultural growth in the society as a whole.

The purpose of our survey was focused on searching new social technologies that can consolidate the Russian people in order to find a nation-wide system of values and ideals, which are the core of the national and patriotic education and upbringing. The searching of these new social technologies shows the need to identify the spiritual moral foundations of the Russian national identity.

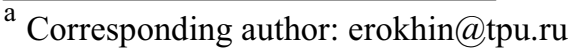

\section{Literature review}

The analysis of scientific literature within the stated problem made by Liliya Kotrutsa shows that patriotic education and upbringing have been thoroughly studied within the latest decades. It is noted that the notions of "patriot" and "patriotism" were completely defined by V.G. Belinsky, N.A. Berdyaev, I.A. Ilyin, A.S. Kalyuzhny et al., the cognitive-emotional content of patriotic consciousness was described by V.G. Belinsky, I.A. Eremin, A.S. Kalyuzhny, V.L. Lenin et al., the philosophical and historical analysis of the nature and the content of patriotism as a social phenomenon is effectively made by N.A. Baranov, V.I. Lutovinov, V.Y. Mikryukov, L. J. Hyun et al. The following aspects are also studied: the formation of civism (E.V. Bondarevskaya, V.E. Gurin, A.A. Zinoviev, A.I. Kochetov, I.S. Maryenko et al.) and civic consciousness (I.S. Artyukhov, L.I. Kartseva, N.I. Lapin, N.A. Masyukov, G.B. Skok et al.), civic position among various social groups of the population in the context of patriotic education and upbringing (D.V. Kirillov, Z.P. Krasnook et al.), the theory of patriotic education and upbringing of military servicemen (A.S. Kalyuzhny, G.A. Kochkolda, A.A. Krupnik, V.Y. Mikryukov, P.I. Obraztsov et al.) [1].

A famous innovative teacher, Vasyl Sukhomlinsky, studied the problem of national and patriotic education and upbringing during the Soviet period. He stated that child's love for the nature, his parents, the elder people, the mother tongue; the heroic Soviet people's acts are the formation features of national and patriotic education and upbringing [2]. The notion of "communist 
patriotism" which included love to "the fairest communist patriotism in the world" appeared in the works devoted to the same problem [3].

Nadezhda Droblenkova paid attention to the fundamental principle of national and patriotic education and upbringing, a call "for the Orthodox faith, the Holy God and the Church, souls, the motherland and the patrimony the God gave us" [4].

Anatoly Vyrschikov found out that directed education and upbringing (military and patriotic in particular) can be considered as a factor of quality improvement of education as a whole [5].

In the post-Soviet period a word "patriot" meant a person "who wishes goodness to the Russian country" [6]. I.A. Pushkarev defined a true patriot as a person "who courageously exposes the enemies of the people, ordinary people, fear-mongers and whimperers..." [7].

In modern literature the notion "liberal patriotism" includes "love and the need to protect the country in which you live and feel very well" [8].

\section{Materials and methods}

However, we are sure that the current system of national and patriotic education and upbringing of younger generations is far from perfect. This system has accumulated patterns and nodding means of influence on an immature person.

This fact shows the importance of the key principals of this phenomenon. It also underlines the need of further research in order to solve a whole complex of problems of national and patriotic education and upbringing.

The research of this problem was conducted at National Research Tomsk State University, National Research Tomsk Polytechnic University, Tomsk Agricultural Institute - a branch of the Novosibirsk State Agrarian University, in 2013-2015. The research involved 536 respondents who participated in surveys, questionnaires, focus groups, and panel discussions. It suggests that the spiritual moral origins of upbringing of Russians are inherently based on traditional spiritual values, which should be understood as:

- Authentic, initially perceived values, which became a historic choice and formed the culture and traditions;

- Culture forming values, influencing the development of the state, people and culture for a long time;

- Values, which formed the basis of people's daily lifestyle, entering its language and customs, have turned into the archetypes of their outlook;

- Values which make the Russian culture distinctive (different from the others) [9].

Analysis of the activity products (youth projects, term papers and diploma theses, exhibition samples, scientific conference collection publications) suggests that the religious values of the traditional Russian confessions such as Orthodox (Russians, Ukrainians, Belarusians, and others), Islam (Tatars, Kazakhs, Chechens, and others), Buddhism (Kalmyks, Tuvinets, Buryats, and others) and Judaism, are at the basis of traditional Russian spiritual values. It is very arbitrary to talk about a complete conformity or people belonging to a particular religion. One can see a lot of Russian Orthodox people or Russian people professing Islam.

In order to support this thesis related to all the nationalities of the Russian multinational country, we will focus on the theoretical analysis of the Russian population traditions. The national systems of upbringing, teaching, and education were based on Russian mentality, outlook, and understanding of the world for more than $80 \%$ of the country population.

A famous Russian philosopher, Nikolay Lossky, in his work "The character of the Russian people", wrote: "The primary and the most profound character trait of the Russian people is its religiosity and the search for absolute Goodness related to it, that is, the Goodness that can be achieved only in the Kingdom of God" ].

When looking into the problem of the tradition in the national and patriotic upbringing and education, we have to take into account the fact that such a system has been already established throughout the country's history, a system which has been effective and historically justified itself. It was a system based on the core fundamental values of the spiritual and moral ideal, implying the priority of the spiritual values over the material ones. This is an ideal, in which the material conditions of life were perceived as important and necessary, but not the top priority. It became possible only in the context of the religious perception of life by our ancestors and predecessors.

This ideal was the main subject of the policy of principles, rather than interests. All the other social systems of society, including the system of national upbringing, were stipulated by such traditional fundamentals. Therefore, another outstanding Russian philosopher Ivan Ilyin tried to understand and systematize the problems of the national and patriotic upbringing. He believed that the construction of such a system is necessary to begin with a renewal of the person's soul, the formation of her/his faith, family holiness, feelings of love for the homeland, patriotism and national pride as opposed to a radical brakeage in the social conditions of existence. According to Ilyin, the task of each generation is to correctly pass this spirit over to new generations in the forms of increasing spirituality, national nobility and international justice. He stated: "Only on this path, the mankind will be able to observe the sacred beginning of the homeland and, at the same time, overcome the temptations of the ill nationalism, as well as the corrupted internationalism..." [11].

All of this gives us a full right to conclude that the spiritual moral foundations, which were put in the foundation of the Russian social system and which proved its viability and social positivity, are religious in nature. These foundations only became possible due to the deep penetration of religion into people's life.

A great Russian researcher in history studies, Sergey Solovyev, considered the foundations of Russian society as: the Governmental power (the skeleton), the armed forces (the muscles), and religion that was compared with the image, which he described as follows: 
“... bones, add up with bones, bind with tendons, cover in flesh, but the spirit is still absent in the new body: this spirit was brought by Christianity". In this description of the religion he referred to the marvelous vision of the Old Testament prophet [12].

The conducted survey is showing that the base of solving the social problems in Russia was a religious tradition. Dostoevsky's words can serve as a proof: "The main thing we have is Orthodoxy. Our nation is great and wonderful because it believes, and because it has Christianity. We, the Russians, are strong, and the strongest of all because we have an immense mass of Orthodox believers. If the nation's faith in Orthodoxy would have been undermined, it would immediately begin to decompose, like the Western nations that have already begun to decompose" [13].

So, one of the defining philosophical approaches to understanding the Russian national, spiritual and patriotic tradition is the position that "the religious belief - the soul, the nerve, the kernel..., is not just a component of the Russian culture, but the foundation" [13].

\section{Results and discussion}

What is the current situation of this ideological attitude to religion and religious traditions in the society? How are statements discussed above being evaluated today?

The current situation in the spiritual life of Russia is characterized by an increase of "traditions loss" tendencies. The survey showed that the portion of the mythological elements is increased in the public mind. There is a visibly growing interest in the irrational, mystical and occult. Distribution of the liberal democratic values of Western origin, not always compatible with the historically-ancestral mentality of the Russian people, is in full swing. Egocentrism is openly advocated under the cover of spiritual freedom, as well as a greed for profit and money, historical and moral nihilism, psychology of pragmatism and antiChristian morality.

It was found that the spiritual-ideological crisis, embracing the broad layers of Russian mass consciousness today, manifests itself in two main forms:

The crisis of national identity, the loss of a sense of historical perspective and lowered self-esteem of the nation, to the historical self-termination;

The breakage of single spiritual space and the loss of national unity in the matter of core values have become the subject of public debates focused on the lost status of "absolute" guidelines.

What are the main factors that caused this crisis?

Firstly, the conducted survey identified a peculiar fashion for reformism. Temptations of alternative knowledge associated with neo-epicurean approaches, reappeared again under the influence of reformist enthusiasm. They set a goal of achieving the highest individualistic happiness for themselves, which should be achieved by any means and in all areas. So, from the point of view of the Christian culture, the main temptation is expressed in the desire to re-think the Christianity as humanism that focuses on life on earth.

Secondly, the success of parallel beliefs (which are not so much syncretic but eclectic, and in a strange way are often taken for scientific opinions) is explained by spiritual poverty. The revolution in manners is adjusting to this secular humanism, taking it as a spiritual guide. The whole intent is for the sake of increasing pursuit of happiness through unbridled sexuality, passion for a profit in any way possible, at the expense of the moral and cultural values.

Thirdly, a grand collapse of collectivism, as well as the logic of democratic pluralist society, serves as an explanation of the process of individualization, which transforms the individual and her/his happiness into the absolute purpose in this world. This purpose is the secularism and attention solely to mundane things. Individualism is becoming the norm of evaluation of society and culture.

Fourthly, pragmatism, which is now taking the place of objectivity and is turning into the criterion of truth, has become a defining feature, a personal experience and a supreme judge.

It is necessary to note a problem of the loss of a sense of the national perspective. "Totalitarian" consciousness truly decayed. It was replaced by catastrophically irresponsible consciousness instead of responsible democratic consciousness, acting in the framework of mutual obligations and remembering the law, morality and national interests.

It should be emphasized that the crisis of a loss of religious tradition is typical (even to a greater extent) for "prosperous" Western society. Here is how the situation in the West is characterized with reference to conclusions of the Synod of European Bishops: “... Many Europeans, especially in educated environment, are used to looking at reality as if God does not exist. They also are used to acting in such a perspective. The man declares himself a source of the moral law, and only a law that a person assigns to herself/himself, is a measure of her/his conscience and actions. She/He is also a measure of culture, even though we all see daily that the society which is called "welfare society" is ill and becoming unmanageable, and those new spiritual tendencies are ripened, caused by the crisis of scientific technical rationality, and there is a revival of pagan religion on the background of hedonism and connivance [14].

Our survey of the local religious situation in the Russian society showed the complexity and contradictions of the situation, as well as the consequences of losing traditions of religious, patriotic and national consciousness.

On the one hand, the survey shows a positive assessment of the spiritual situation. A situation has been developed in the society, when religion, which has been recently persecuted and was on the edge of extinction and elimination, has become the most attractive sphere of social existence. The survey showed that "positive" or "very positive" attitude to Orthodoxy is a belief of the overwhelming majority of respondents $-\mathbf{8 8 \%}$, and only $4 \%$ of respondents have "negative" or "very negative" 
attitude. This positive attitude to religion is so great that it even covers the majority of those who call themselves atheists, $66 \%$ of atheists have a positive attitude towards Orthodox.

However, this is only a superficial view. It is obvious that there is a big difference between "relation to religion" and "personal commitment to a religion". Proreligious spirits and church life are very far from each other, and they cannot be equal.

That is why it is necessary to go down to a deeper level of survey in order to identify which ideological reality is hidden behind the declared faith. At the world outlook level (according to 2014 survey) a picture of deep emptiness of declared religious faith is as follows: $30 \%$ of the "believers" believe in reincarnation, $41 \%$ of "believers" believe in astrology, and only 7\% of respondents go to church at least once a month. As a result of a more careful analysis of the problem, there turned out to be $4 \%$ of "traditional believers" in the population sample.

That is why, the following statement is possibly correct: "Religious renaissance" currently experienced in Russia, remains largely outside, hardly affecting the perception of depth of the world outlook. The religious revival is booming from the outside, but there are no significant changes occurring within the deep layers of the religious consciousness.

It is not the religion that beats atheism in Russia, but religion and atheism are retreating in front of the growth of ideological uncertainty and ideological eclecticism. The ufology, extrasensorics, astrology, belief in energy vampires, witches, shamans, black and white hereditary magicians and sorcerers, reincarnation of the soul, etc, currently exist in the public consciousness of our people. Belief in reincarnation is often generated by people not dividing the tenets of Buddhism and Hinduism. All of the above stated provides the elements that are not structured and not integrated into a logical system, such as the belief in God in general, belief in progress, democracy and free market.

\section{Conclusion}

Thus, the conducted survey gives a basis to make a conclusion that the traditional religiosity retreats before the ideological eclecticism. The increase of ideological uncertainty is more obvious, which (depending on the taste), can be called "spiritual entropy" and is now separated from strong and fundamental structures. The prospects of rigid morality are not visible either, and, most likely, the situational morality will dominate in the near future.

The solution of the problem of building a new concept of national and patriotic upbringing and education may be facilitated by the creation of informational educational space in the field of education in order to disseminate a wide range of non-ideological, truly scientific knowledge of religion. It will also require a restoration of adequate world outlook concepts to look at a social role and significance of the religion. This step is stipulated by the fact that the existing socio-cultural situation will result in the pragmatism and extreme individualism to take the first place over the fundamental values. In conclusion, the given consequences will make us re-think the fact that traditions are the root system of any nation, feeding its growth and (under certain conditions) ensuring its prosperity in the family of other nations.

\section{References}

1. L.N. Kotruca, Formirovanie patrioticheskogo soznanija u starsheklassnikov v shkol'noj sisteme vospitanija. Diss. kand. ped. n. [The formation of Patriotic consciousness among high school students in the system of school education. PhD thesis.] (Majkop, 2009)

2. V.A. Suhomlinskij, Rodina $v$ serdce. [The Motherland is in the heart.] (Moskva, Molodaja gvardija, 1980)

3. A.S. Milovidov, Kommunisticheskaja nravstvennost' $i$ voenno-patrioticheskoe vospitanie. [Communist morality and military-Patriotic education.] (Moskva, Znanie, 1979)

4. N.F. Droblenkova, Novaja povest' o preslavnom Rossijskom carstve $i$ sovremennaja ejo agitacionnaja patrioticheskaja pis'mennost'. [A new tale of the glorious Russian Kingdom and its modern propaganda Patriotic writings.] (MoskvaLeningrad, Akademija nauk SSSR, 1960) (Rus.).

5. A.N. Vyrshhikov, Military-Patriotic education of schoolchildren: Theory and practice (Moskva, Pedagogika, 1990)

6. M.M. Krom, To the question about the time of the patriotism idea origin in Russia (Moskva, 1994)

7. I.A. Pushkareva, The idea of patriotism in Soviet and Russian pedagogics / for the classroom teacher (Moskva, 2011)

8. A.K. Bykov, Pedagogika, 9, 21-25 (2010)

9. T.A. Kostjukova, Problems of professional identity of future teachers in traditional Russian spiritual values: doctoral thesis (Tomsk, 2002)

10. N.O. Lossky, The character of the Russian people Moskva (1999)

11. I.A. Ilyin, Axioms of religious experience (Moskva, 1993)

12. V.N. Solovyev, Justification of goodness: moral philosophical writings: in 2 vol., vol. 1. (Moskva, 1990)

13. F.M. Dostoevsky and Orthodoxy (Moskva, 1995)

14. Cardinal Paul Poupard, The role of Christianity in the cultural identity of European people [http://agnuz.info/app/webroot/library/140/540/pag e03.htm] (accessed date12.02.2016). 